\title{
TVORBA ÚZEMNÉHO PLÁNU MESTA KOŠICE
}

\begin{abstract}
Prednáška je zameraná na prípravu nového územného plánu mesta Košicez hl'adiska vecných ciel'ov a princípov, ktoré sa v jeho riešení uplatňujú, a $\mathrm{z}$ hl'adiska metodického prístupu $\mathrm{k}$ jeho tvorbe. $\mathrm{V}$ prvej časti bude prednáška zameraná na charakteristiku mesta Košice, jeho polohu v prírodnom prostredí a úlohu v sídelnej štruktúre, vývoj mesta v jednotlivých obdobiach a spoločenských zriadeniach a vymenovanie pozitívnych a negatívnych faktorov mesta. V druhej časti bude prednáška zameraná na hlavné princípy a ciele, na ktorých je koncepcia tvorby nového územného plánu založená a charakteristiku novej metódy spracovania územného plánu.
\end{abstract}

Kl’účové slová: územný plán mesta, Košice, koncepcia tvorby, nová metóda spracovania

\section{Súčasnost’ mesta}

Mesto Košice leží v juhovýchodnej časti Slovenska, vKošickej kotline, jeho nadmorská výška $\mathrm{v}$ hraniciach administratívneho územia mesta sa pohybuje vrozmedzí od cca 200 m n.m. na juhu až po cca 800 m n.m. na severe. Košickú kotlinu odvodňuje rieka Hornád so svojimi l'avostrannými apravostrannými prítokmi. Mesto Košice reprezentuje zhl'adiskavel'komestského typu urbanizácie druhú najväčšiu koncentráciu obyvatel'stva aekonomických aktivít vSR, vsúčasnosti má mesto cca 250000 obyvatel'ov. Zhl'adiska funkcie mesta vsídelnej štruktúre sú Košice krajským mestom svýrazným záujmovým územím, koncentrujú sa tusprávne zariadenia aOV vyššieho významu, mesto je zdrojom pracovných príležitosti vo viacerých sektoroch (denne dochádza do mesta asi 50000 obyvatel'ov), vmeste sa nachádza letisko. Mesto Košice tvorí dôležitý dopravný uzol, ktorý je súčast'ou dopravných sietí európskeho významu (obr. 1).

1 Viktor Malinovský, TechnickejUniverzity v Košiciach, Katedra Architektúry, Rázusova 44, 04001 Košice; tel/fax: +421 55/62 333 80, +421 905435 705; e-mail: vmalinovsky@ stonline.sk 


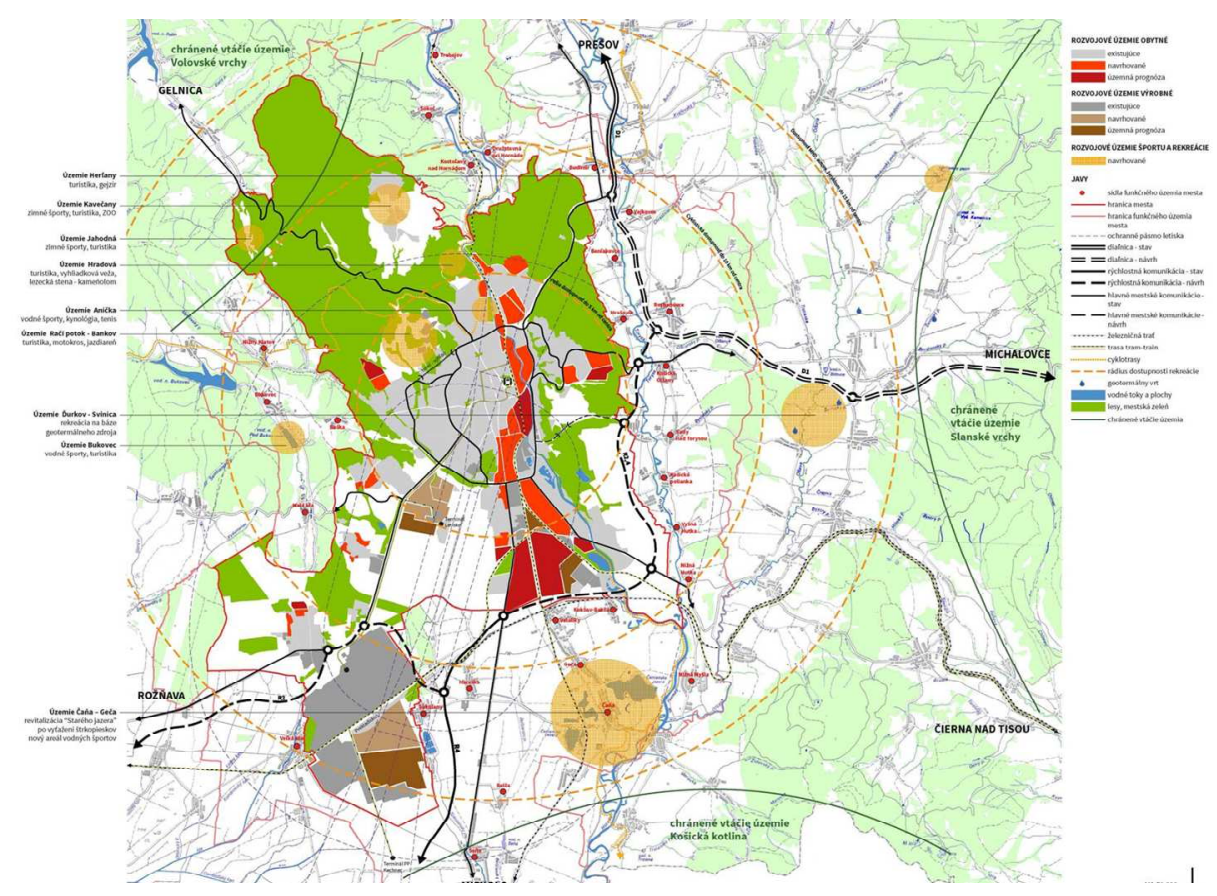

Obr. 1. Úloha mesta Košice v sídelnej štruktúre

\section{Historický vývoj}

Košice boli založené v stredoveku, priestorová štruktúra mesta sa vyvíjala okolo námestia šošovkovitého tvaru, orientovaného v severojužnom smere. Dížka námestia je cca $800 \mathrm{~m}$, v najširšom mieste má námestie približne $85 \mathrm{~m}$.

Mesto Košice má svoju jasnú a čitatel'nú dopravnú štruktúru, vytvorenú železnicou (s jasnou polohou železničnej stanice) a radiálno-okružným systémom automobilovej dopravy.

Urbanistický vývoj mesta najvýraznejšie ovplyvnili dva faktory:

- v 19. storočí zavedenie železnice,

- v 20. storočí výstavba hutníckeho kombinátu.

Nárast počtu obyvatel'ov vyvolal potrebu výstavby nových sídlisk v meste, ktoré možno rozdelit' do dvoch skupín:

- sídliska umiestnené západne od jadrového mesta (sídlisko Terasa, sídlisko Košického vládneho programu),

- sídliská umiestnené východne od jadrového mesta (sídlisko Nad Jazerom, sídlisko Dargovských hrdinov, sídlisko Ťahanovce) (obr. 2).

Čo sa týka priestorovej štruktúry KE, priestorová štruktúra jadrového mesta sa výrazne odlišuje od priestorovej štruktúry sídlisk, ktoré vyrástli po roku 1950, a je poznačená vtedajšími teóriami urbanizmu (Aténska charta). 


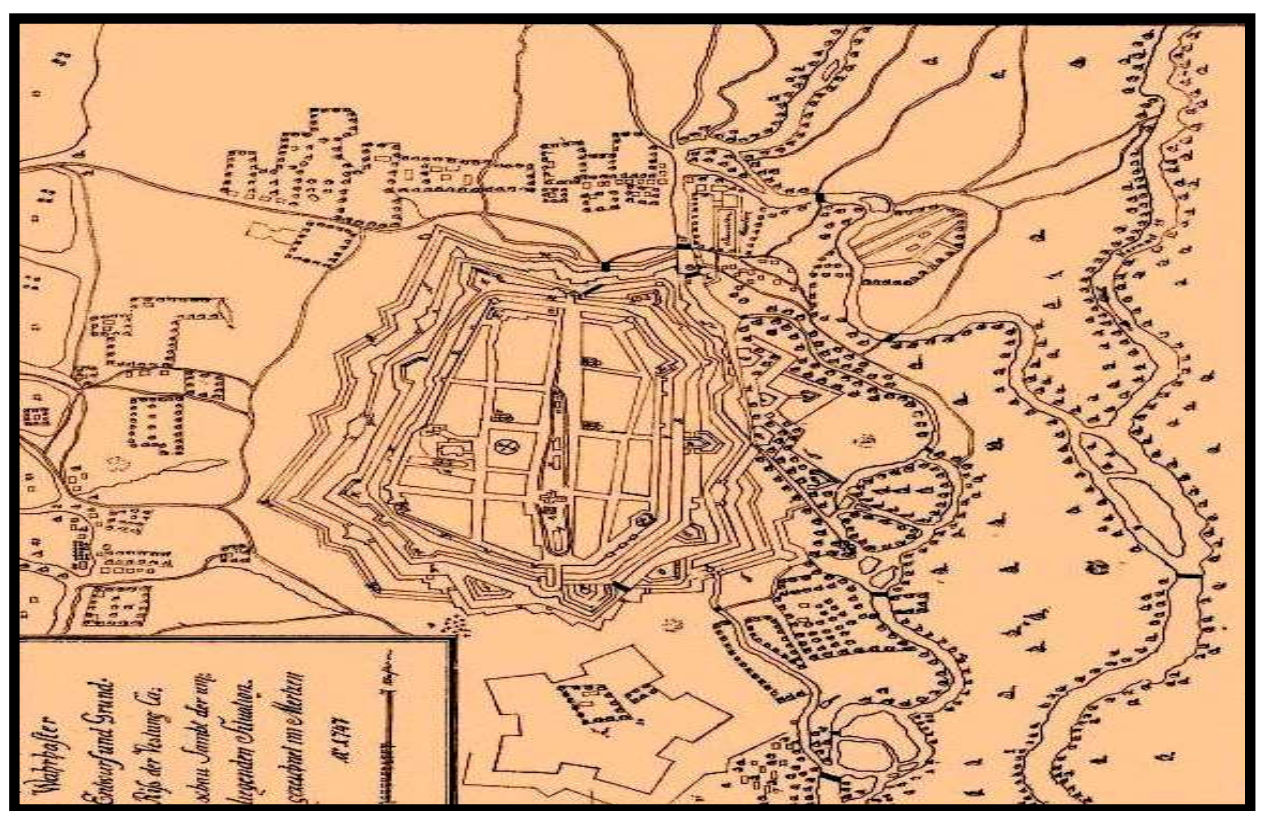

Obr. 2. Pôdorys pevnosti Košice (kresba z roku 1747)
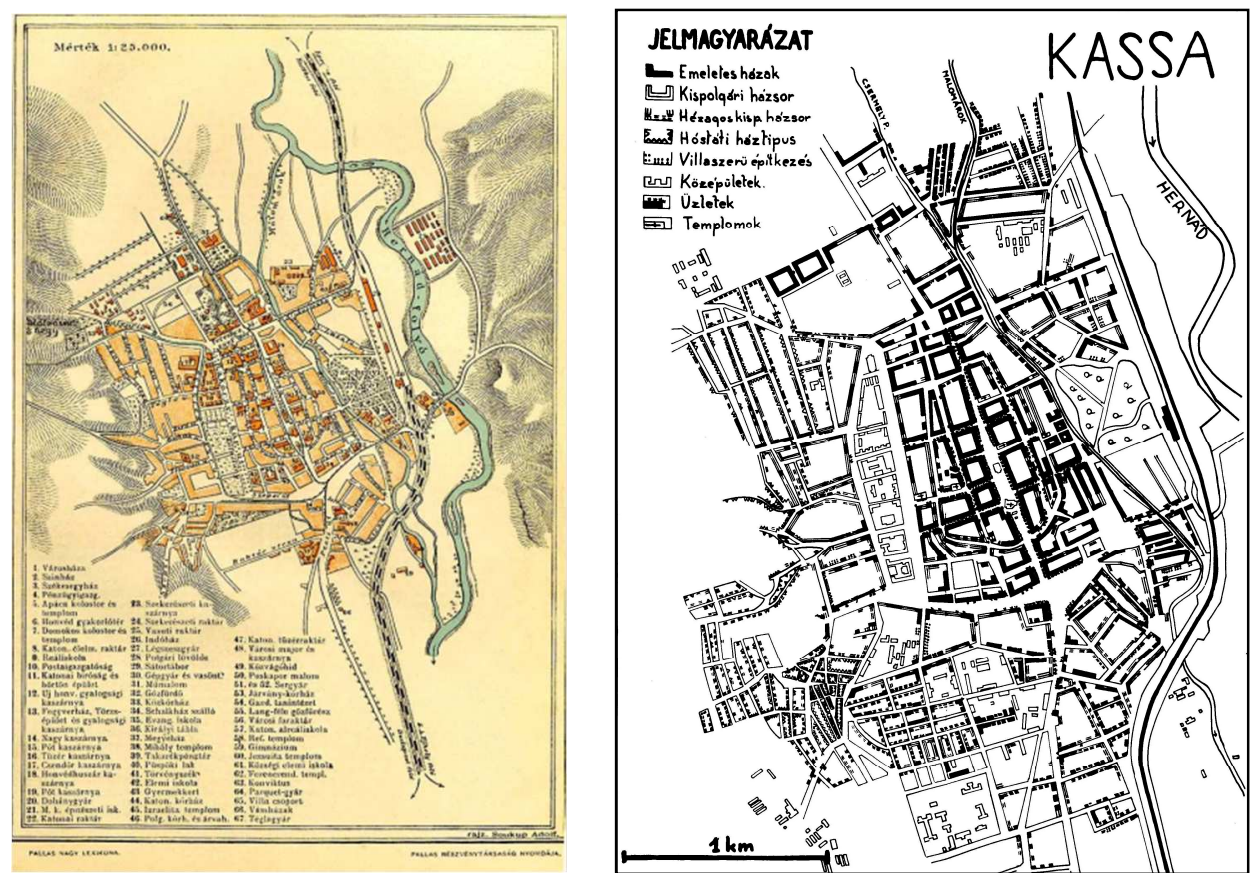

Obr. 3. Na konci 18. stor. bol zrušený štatút Košíc ako pevnosti, čo umožnilo postupné splynutie vnútorného mesta s predmestím 


\section{Koncepcia tvorby územného plánu}

Pri tvorbe územného plánu mesta Košice vychádzame $\mathrm{z}$ analýzy mesta a definovaní jeho pozitívnych a negatívnych stránok, znázornených na nasledujúcom obrázku 4.

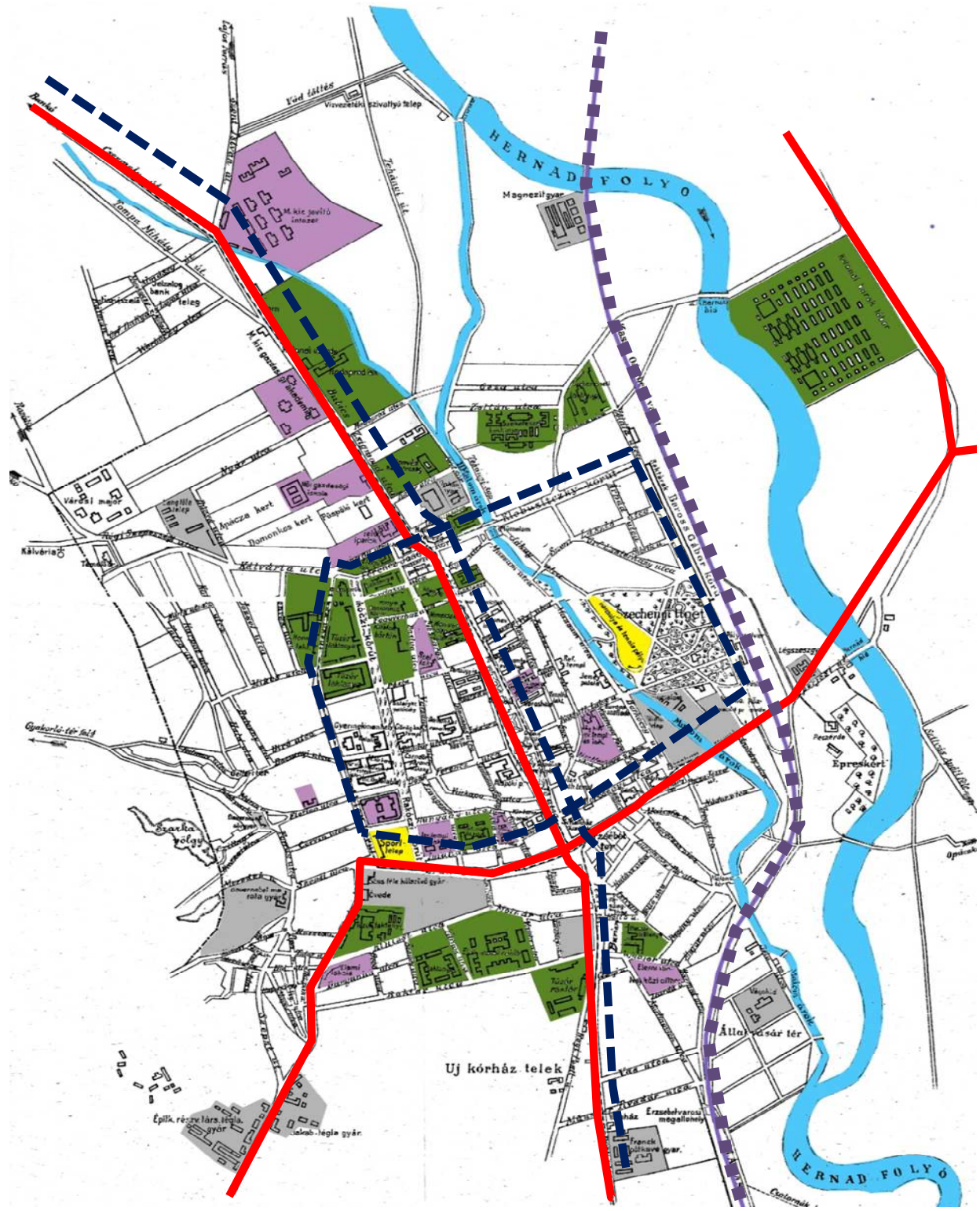

Obr. 4. Dopravná štruktúra mesta na konci 19. storočia - cesty, železnica (1860), mestská doprava (1891) 


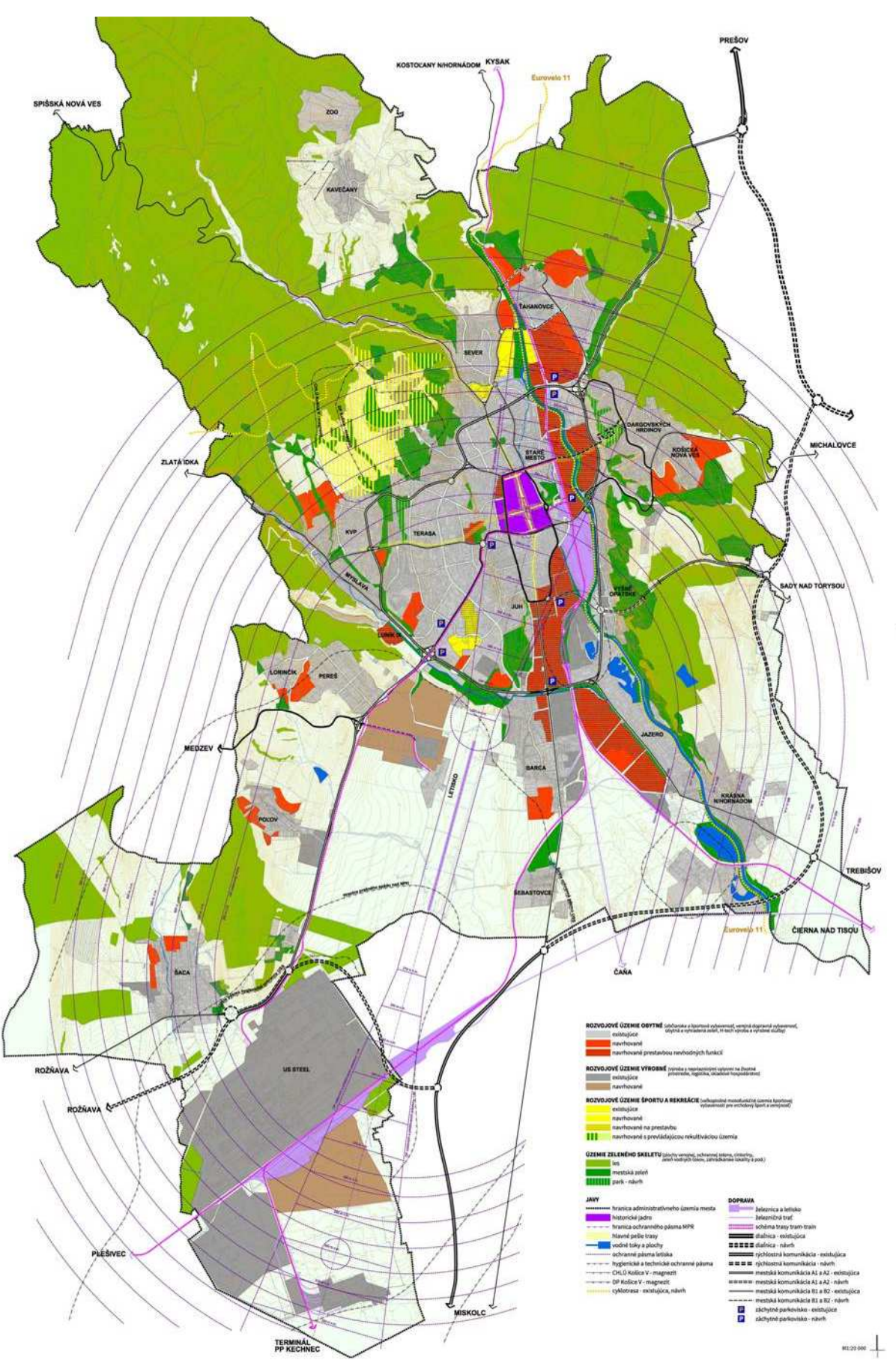

Obr. 5. Pozitívne a negatívne stránky mesta 


\subsection{Pozitívne stránky mesta}

- zachovaný pôdorys a kompaktná architektonická štruktúrahistorického jadra mesta vyhláseného za mestskú pamiatkovú rezerváciu

- koncepčne založený základný dopravný skelet mesta a jeho pripravované napojenie na nadradený systém dial'nice a rýchlostných ciest

- kvality bezprostredného prírodného prostredia mesta - mestské lesy a rieka Hornád

- význam mesta ako centra medzinárodného významu (karpatský euroregión) a centra regionálneho významu (košicko - prešovskét’ažisko osídlenia)

- existencia medzinárodného letiska

\subsection{Negatívne stránky mesta}

- bariéry medzi centrom a riekou (železnica, nevhodná zástavba), ktoré bránia plnohodnotnému uplatneniu rieky v organizme mesta,

- rozsiahle plochy nevhodných funkcií a nekvalitnej stavebnej štruktúry (Južná trieda a Pri bitúnku, nákladná manipulačná čast’ železničnej stanice), ktoré siahajú až do centrálnej časti mesta,

- rozsiahle plochy brownfieldov, najmä bývalá Magnezitka a ban̆a Bankov,

- záplavové územie pozdĺž rieky Hornád,

- nedostatočné previazanie okolitej lesnej zelene so zastavaným územím mesta asystémom mestskej zelene, absencia verejných parkov najmä v južnej časti mesta,

- chýbajúce členenie mesta na menšie urbanistické štruktúry (štvrte, sektory).

\section{Princípy nového územného plánu}

Našim cielom je aplikovat' v novom územnom pláne nasledujúce princípy.

\subsection{Princíp kompaktného mesta}

- vytvára mestské prostredie s atraktívnymi verejnými priestormi,

- skracuje trasy dopravnej a technickej infraštruktúry,

- znižuje intenzitu mobility obyvatel'stva,

- znižuje investičné a prevádzkové náklady na verejnú dopravnú a technickú infraštruktúru,

- šetrí prírodné prostredie,

- kompaktné urbánne formy sú štandardom rozvoja miest v súčasnosti (obr. 6). 


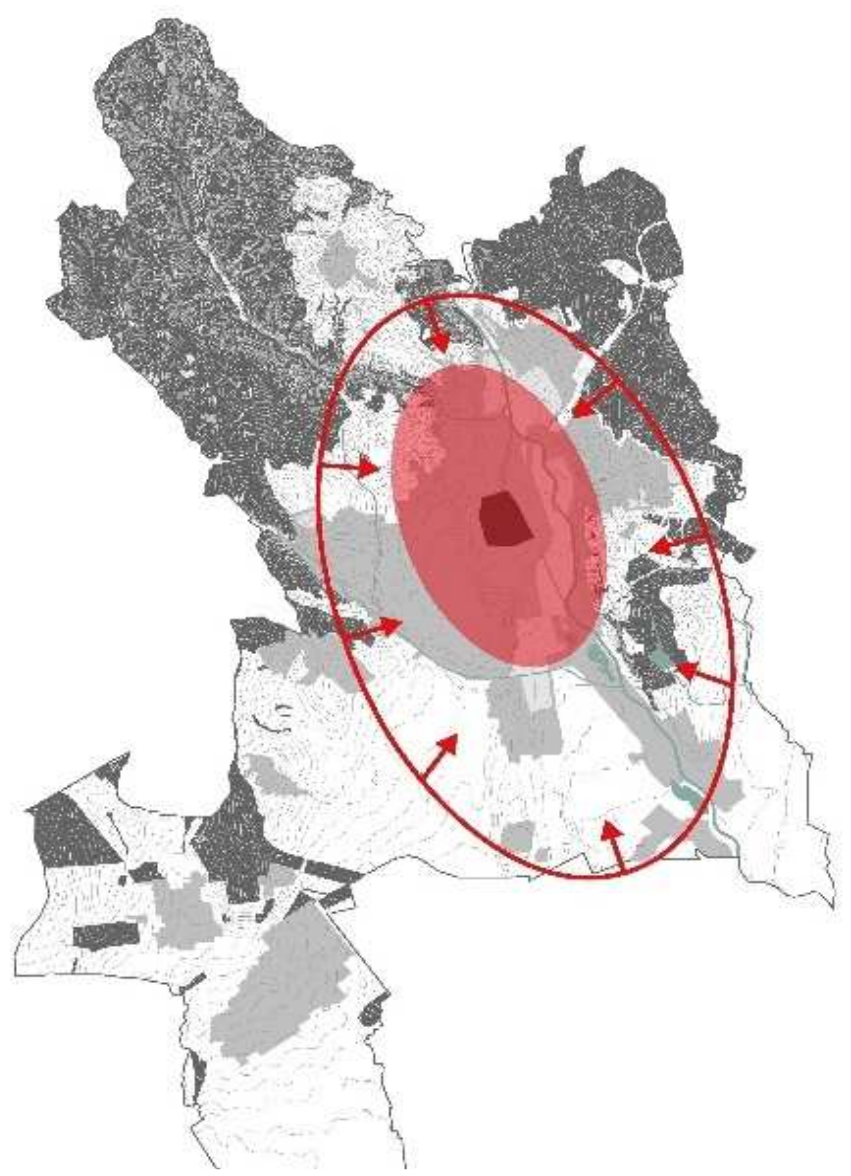

Obr. 6. Princíp kompaktného mesta

\subsection{Princíp funkčno-ekonomický}

Filozofia sút’ažného návrhu vychádza z:

- analýzy hustoty obyvatel'ov na ha zastavaného územia (cca 36 obyvatel’ov na ha v súčasnosti)

- sútažný návrh člení lokality na nové a prestavbové.

Nové lokality nadväzujú na zastavané územie a súprevzaté z územného plánu mesta v minimálnom rozsahu, najmä z dôvodu vybudovanej kapacity inžinierskych sietí a dopravného napojenia.

Prestavbové lokality sú najmä územia pozdĺž rieky Hornád a pozdíľ Južnej triedy s využitím jestvujúcej dopravnej a technickej infraštruktúry, ktorýmsa prinavráti mestský charakter a mestské využitie. 


\subsection{Princíp väzby s prírodným prostredím}

V sút’ažnom návrhu je vyjadrený vytvorením, ,zelených kompozičných osi“, ktoré prepájajú exkluzívne prírodné prostredie mesta (Čierna hora, Volovské vrchy) s mestskou zeleňou a zeleňou pozdĺž rieky Hornád a sprievodnou zeleňou ostatných vodných tokov.

„Zelená kompozičná os“ je artikulovaná:

- v dostatočne vol’ných územiach: ako výrazné plochy zelene a parky

- v stiesnených územných podmienkach: ako stromoradia doplnené plochami trávnikov, ,zelených“ striech a fasád bytových domov

Kvalitné prírodné prostredie navrhujeme využit' pre rekreačno-športové aktivity a zároveň optimalizovat' podiel plôch verejnej zelene na obyvatel'a (obr. 7).

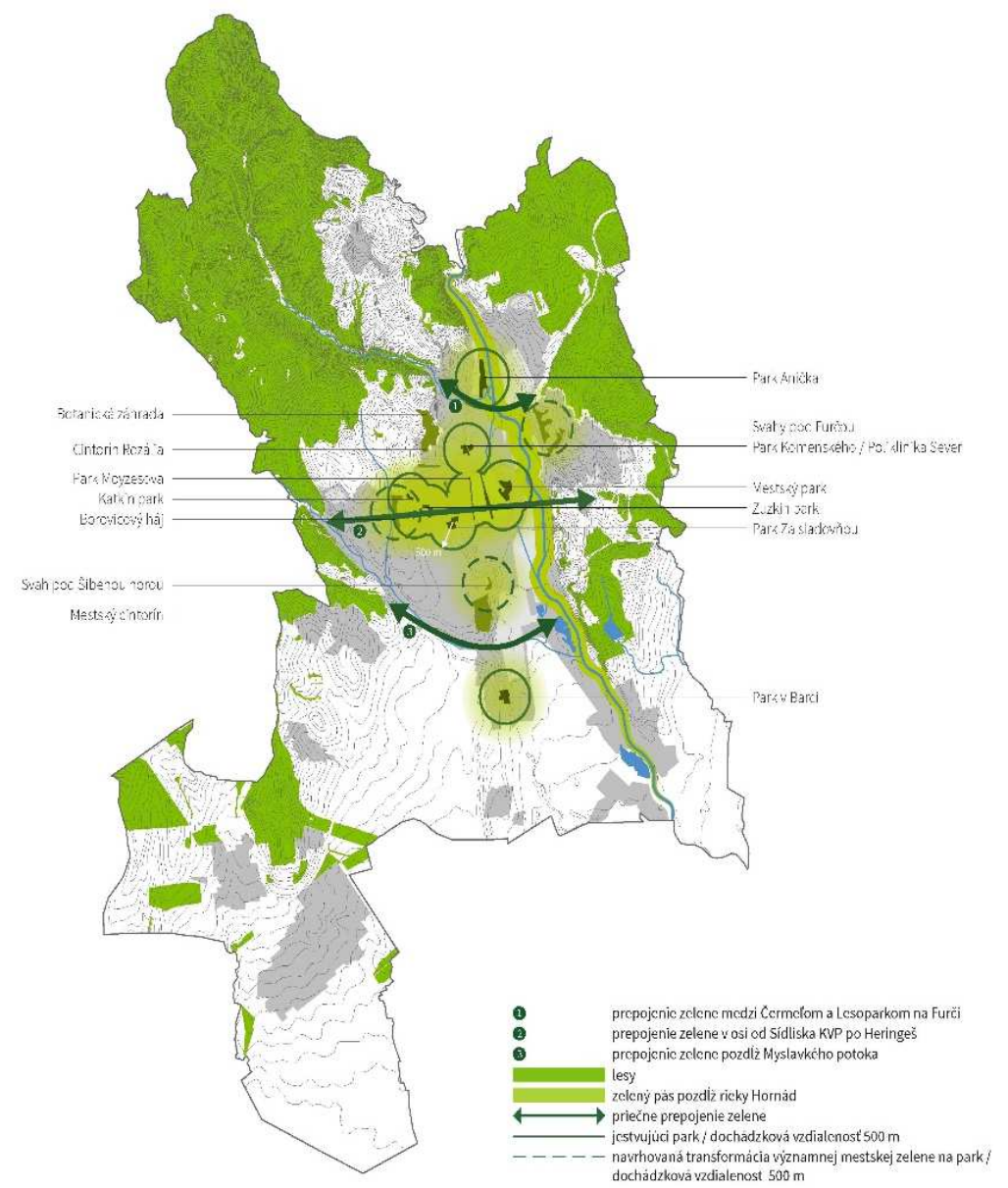

Obr. 7. Mestská zeleň 


\subsection{Princíp návratu do mesta}

Spočíva $\mathrm{v}$ udržaní súladu prírodnej a urbánnej krajiny ukončením extenzívneho rozvoja mesta a postupnou intenzifikáciou využitia zastavaného územia a zvyšovaním kvality urbánnej štruktúry mesta (obr. 8).

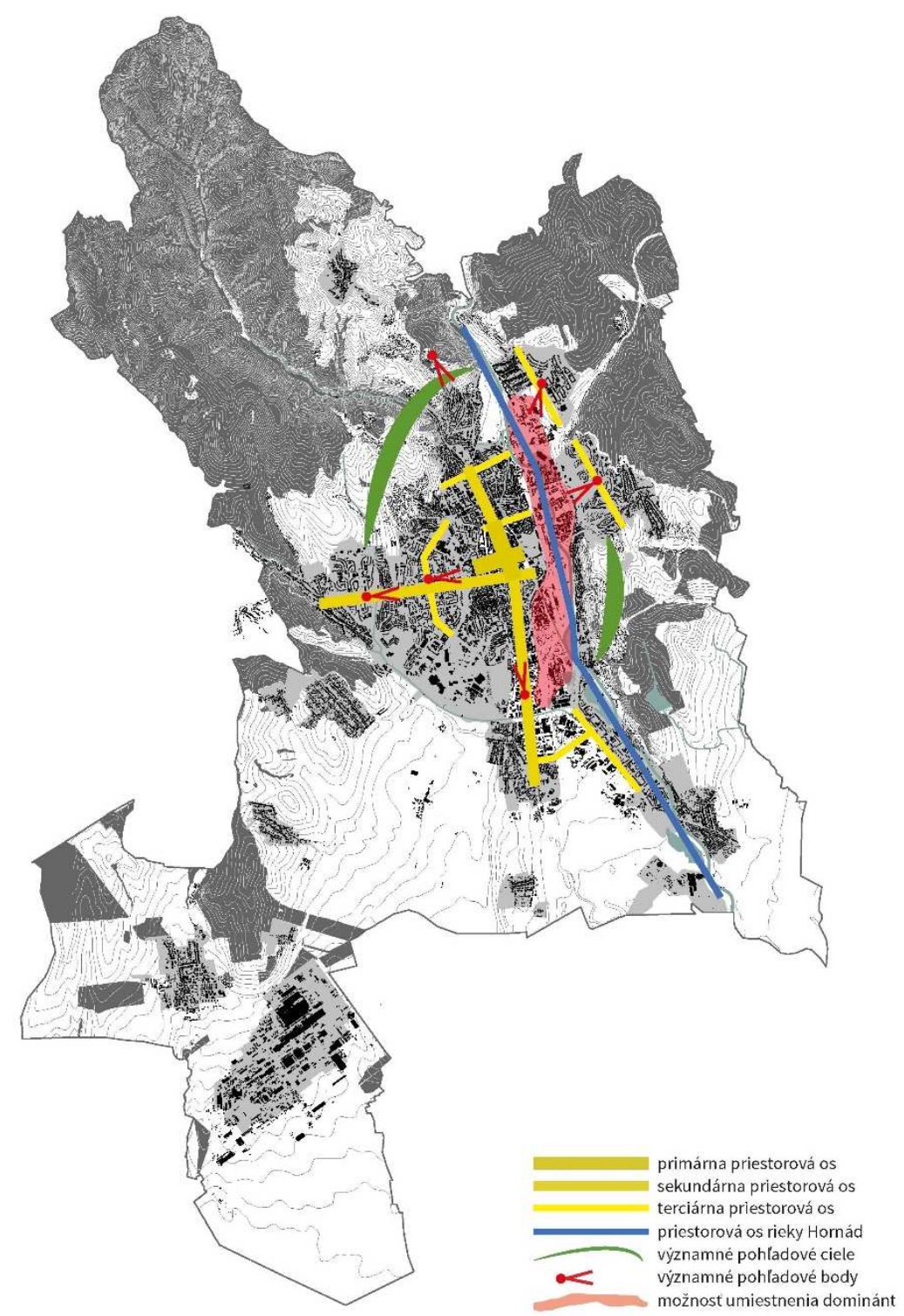

Obr. 8. Priestorové usporiadanie (výškové zónovanie) 


\section{Funkčné členenie mesta v duchu Aténskej charty}

Pri tvorbe územného plánu mesta vychádzame z miernejšieho funkčnéhočlenenia mesta,ktoré jev súčasnom ÚPN členené na zóny v duchu Aténskej charty. Naše funkčné členenie mesta je nasledovné:

\subsection{Obytné územie}

Predstavuje integrované funkcie:

- bývania všetkých foriem,

- občianskej a športovej vybavenosti (okrem vel'kých športových zariadení),

- zariadenia verejnej dopravnej vybavenosti,

- obytnej a verejnej zelene,

- drobnej nezávadnej výroby a výrobných služieb

Návrh rozlišuje dve formy:

- čast' nezastavaných plôch v dotyku so zastavaným územím, prevzaté z platného územného plánu mesta

- plochy určené na prestavbu

\section{2. Územie športu a rekreácie}

Predstavuje vel'koplošné územia rekreácie a športovej vybavenosti celomestského významu:

- ide najmä o plochy v priestore „Anička“, kde je navrhovaný aquapark a vodácky areál

- časti všešportového areálu

- areál bývalej bane Bankov, ktorý je navrhnutý na rekultiváciu a využitie pre rôzne druhy športov

\subsection{Výrobné územie}

V sút'ažnom návrhu je ekonomická základňa mesta výrobného charakteru vyjadrená nasledovne:

- $\quad$ spracovatel'ský priemysel (výroba) s nepriaznivými vplyvmi na životné prostredie a vysokými nárokmi na dopravnú obsluhu, zariadenia logisticky koncentrované na území v blízkosti US Steel-u (funkčné územie výrobné Bočiar).

- hi-tech výroba, progresívne technológie, výrobné služby a infraštruktúra občianskej vybavenosti (veda, výskum) sú integrované najmä do plôch priemyselného parku Pereš a do obytného územia drobná nezávadná výroba, remeselná výroba, obchod a služby je rozptýlená v obytnom území. 


\section{4. Územie zeleného skeletu mesta}

Predstavuje ucelené rozsiahlejšie plochy zelene zvyšujúcej kvalitu ovzdušia (ochranná, verejná, cintoríny, zeleň vodných tokov, záhradkárske lokality):

- návrh zdôrazňuje základnú kostru zelene - lesopark a sprievodnú zeleň vodných tokov, ktorú doplńna o priečne koridory tvorené alejami pri komunikáciách a disponibilnými plochami pri nich.

- zvláštny dôraz sa kladie na posilnenie verejnej zelene okolo Hornádu a v územiach určených na prestavbu (obr. 9).

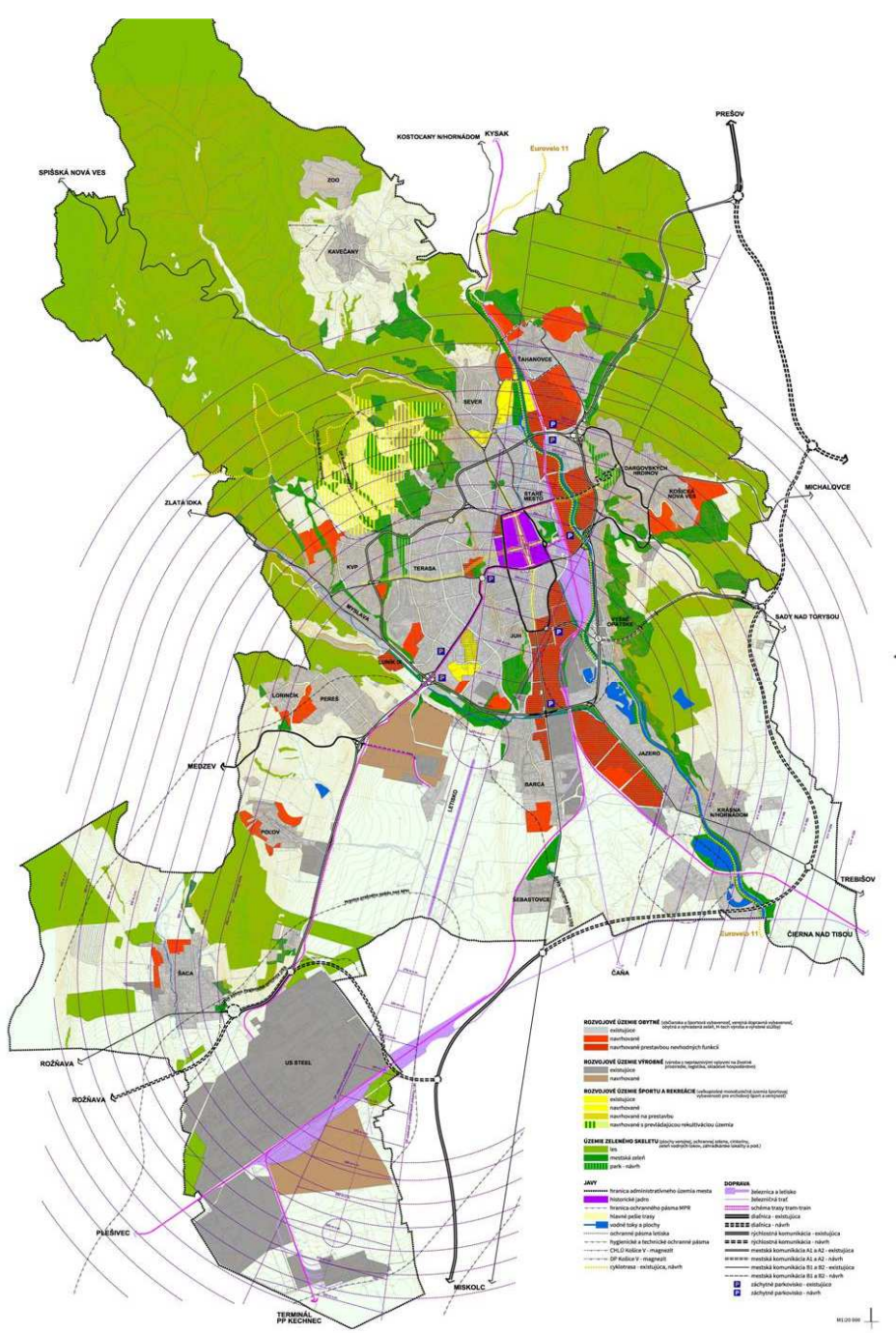

Obr. 9. Funkčné členenie mesta 


\section{Dynamická a statická doprava}

V riešení dynamickej a statickej dopravy vychádzame z nasledovných princípov:

\subsection{Dynamická odprava}

- z koncepčne založenej dopravnej kostry v meste

- vonkajší aglomeračný polokruh, vnútorný rýchlostný mestský okruh

- uprednostňuje MHD, pešiu a cyklistickú dopravu

- akceptuje pripravovaný integrovaný systém osobnej kol'ajovej dopravy(tram-train), navrhuje jeho trasu na letisko, navrhuje nový terminál intermodálnej prepravy v lokalite Bočiar

- vytvára odstupňované zóny prístupu vozidiel IAD, navrhuje systém „chytrého parkovania“"

\subsection{Statická doprava}

Navrhuje výstavbu hromadných garáži a odstavných plôch na mieste neefektívnych plôch boxových garáží, redukuje manipulačné plochy južne od železničnej stanice (obr. 10).

\section{Záver}

- Ciel'om je vytvorit' ÚPN, ktorý sa bude dat' schválit', a bude sa ním riadit' akákol'vek investičná výstavba vadministratívnych hraniciach mesta Košice

- Vol’nejšie funkčné členenie mesta

- ÚPNbude koncipovaný ako otvorený geografický informačný systém (GIS) sprístupnený cez mapový webportál mesta

- Zapojenie odbornej i laickej verejnosti do celého procesu plánovania rozvoja mesta

- Samotný ÚPN, aj ked' bude akokol'vek múdro a kvalitne spracovaný a bude schválený, je len "mŕtvy" dokument....

Vel'mi t'ažkou organizačnou a manažérskou úlohou bude uviest' ÚPN do života a hlavne zabezpečit' to, aby sa ÚPN dodržiaval, čo je jeho najdôležitejšou úlohou. 


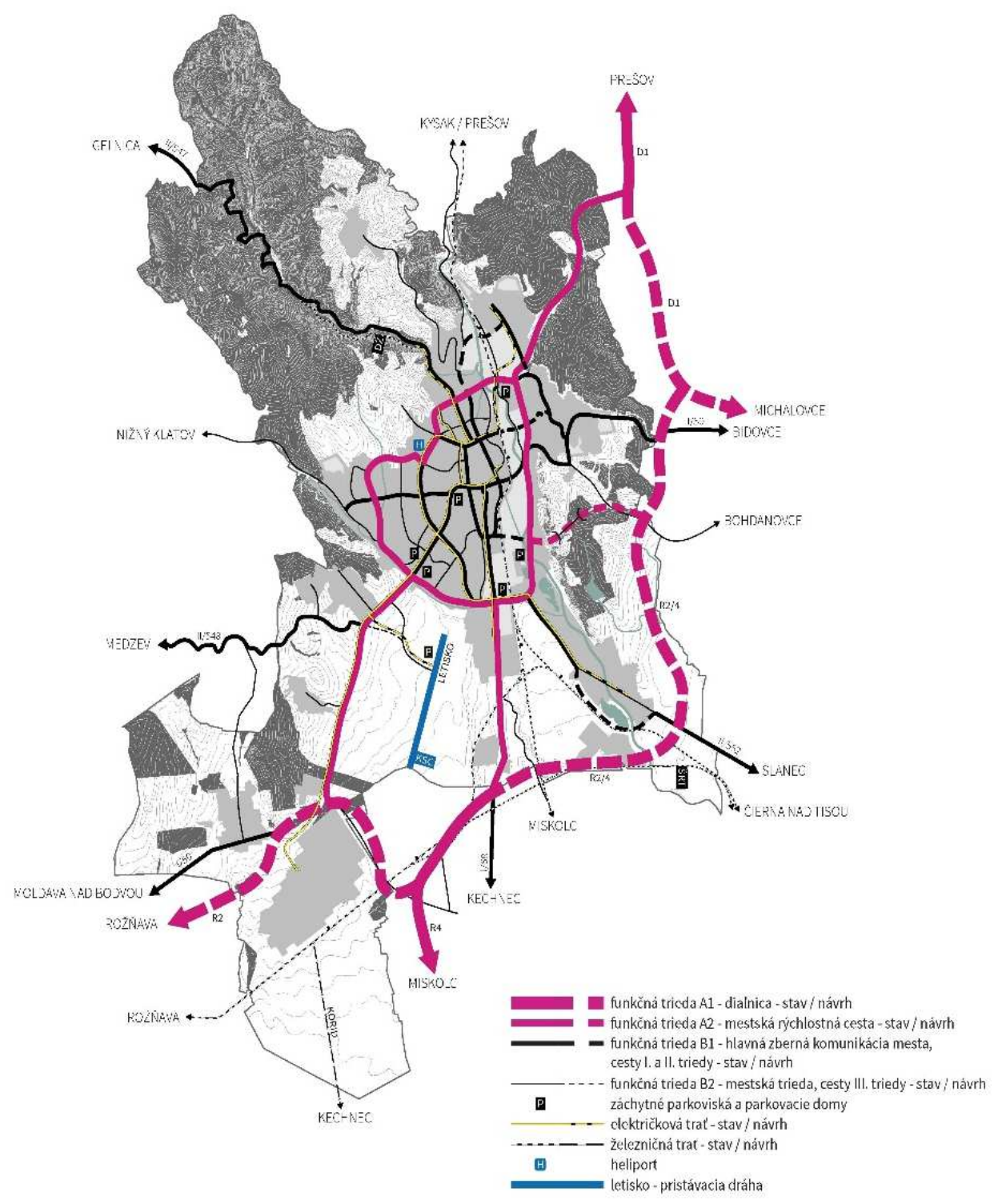

Obr. 10. Dopravná kostra mesta

\section{Literatúra}

[1] Aktualizácia prvkov regionálneho ÚSES okresoch Košice I-IV, SAŽP CER Košice, 2006

[2] Arka - architektonická kancelária, spol. s.r.o.: Potenciálne možnosti územného 
rozvoja a analýza doterajších zámerov z hl'adiska stratégie programu ,zdravé mesto Košice“, Košice, 1992

[3] Atlas krajiny Slovenskej republiky, MŽP SR, SAŽP, Bratislava, 2002

[4] Halaga, O.R.: PočiatkyKošíc a zrodmetropoly, Košice, 1992

[5] Iglódy K., Kolesárová J.: Doprava a urbanistický rozvoj mesta z pohl’adu nového územného plánu mesta, Košice, 2015

[6] Inventarizácia záhradkárskych lokalít na území mesta Košice, ÚHA mestaKošice, november 2010

[7] Jiroušek, A.: Košice na začiatku tretieho tisícročia, Vydavatel'stvoKošice, 2003

[8] Koncepcie rozvoja športu mesta Košice na roky 2015-2020, Uznesenie Mestskeho zastupitel'stva v Košiciach č.90/2015

[9] Koncepcia riešenia statickej dopravy v mesteKošice, EEI s.r.o. Bratislava, 2013

[10] Mencl V.:Středověká města na Slovensku, Bratislava, 1938

[11] Polla, B.:Košice - Krásna. K stredovekým dejinám Krásnej nad Hornádom. Košice, 1986.

\section{CREATION OF THE MASTER PLAN OF THE CITY OF KOSICE}

\section{S u m m a r y}

The lecture is focused on the preparation of a new territorial plan of the city of Košice in terms of the objectives and principles used in its solution. The terms used in the creation of the methodical approach. The lecture will focus on the characteristics of the city of Košice. Its location in the natural environment. Its role in the settlement structure, the development of the city in particular periods and social institutions and the appointment of positive and negative factors of the city in the first part. In the second part of the lecture we will focus on the main principles and objectives underlying the concept of creating a new zoning plan established and characterization of a new method of processing land-use plan.

Keywords:Town plan, Košice, concept of creation, new method of processing 